\title{
Comparison of maternal and fetal morbidity between Patwardhan method of second stage lower segment caesarean section and conventional "push and pull" method
}

\author{
Kishorkumar Hol, Sneha Trivedi, Shruti Jaiswal*, Sameer Darawade
}

Department of Obstetrics and Gynecology, Smt. Kashibai Navale Medical College and General Hospital, Pune, Maharashtra, India

Received: 05 September 2019

Accepted: 07 October 2019

\section{*Correspondence:}

Dr. Shruti Jaiswal,

E-mail: shrutimjaiswal@gmail.com

Copyright: () the author(s), publisher and licensee Medip Academy. This is an open-access article distributed under the terms of the Creative Commons Attribution Non-Commercial License, which permits unrestricted non-commercial use, distribution, and reproduction in any medium, provided the original work is properly cited.

\begin{abstract}
Background: To compare Maternal and fetal morbidity between Patwardhan method of second stage LSCS and conventional "push and pull" method.

Methods: A retrospective study of all LSCS performed in second stage of labour consisted of all cases delivered by Patwardhan method compared with cases delivered by Push method during 3 years from January 2016 to December 2018 in Smt. Kashibai Navale Medical College Pune, Maharashtra, India.

Results: A total of 89 patients underwent second stage LSCS from January 2016 to December 2018. A total of 37 patients were delivered by Patwardhan's method and 52 patients were delivered by Push method. Uterine incision extension was more in the push and pull method when compared to Patwardhan technique. Same was true for the traumatic PPH blood transfusion which was significantly high in push and pull method as compared. Neonatal morbidity was significantly less in Patwardhan's method as compared to Push method.

Conclusions: As the maternal and fetal complications are seen to be considerably less in Patwardhan's method than the conventional Push method our study concludes that Patwardhan's method for delivering baby in second stage LSCS confers greater advantage.
\end{abstract}

Keywords: Neonatal and maternal morbidity, Obstructed labour, Patwardhan method, Push and pull method, Second stage section

\section{INTRODUCTION}

Patwardhan's method is a method introduced by Dr. Balchandra Patwardhan in order to deliver baby by LSCS in second stage of labour. The technique commonly referred to as "shoulders first technique" was introduced by Dr. Patwardhan and his colleague Dr. Nargis Motashaw in 1957. This method was published by him in Journal of Obstetrics and Gynaecology India in 1957 According to studies the incidence of second stage sections are about $1 / 10^{\text {th }}$ of total sections. ${ }^{1}$ Caesarean sections done at full cervical dilatation with impacted head are difficult and associated with increased incidences of Maternal and Fetal morbidities. Methods employed for disengaging the fetus contribute to varying complications.

Potential problems include difficult delivery of fetus, extension of uterine incision, uterine artery laceration, broad ligament hematoma. Foetal complications include 
low APGAR and NICU admissions. Extension of the uterine incision and injury to the surrounding structures during LSCS is common in obstructed labour, when the hand is forcibly introduced into the pelvis to deliver the head which is impacted and jammed in the pelvis, since the lower uterine segment is oedematous and fragile. ${ }^{2}$

\section{Patwardhan technique}

In case of occipito-anterior and transverse positions with the head deeply impacted in the pelvis, incision is made in the lower uterine segment. Shoulders are present usually at incision level in deeply engaged head, the anterior shoulder is delivered out by hooking the arm first by hooking the arm. With gentle traction on this shoulder, the posterior shoulder is also delivered out. Next, the surgeon holds the trunk of baby gently with both thumbs parallel to spine and with fundal pressure given by assistant the buttocks are delivered followed by legs. Now the baby's head which is the only part of the foetus which is still inside the uterus, is gently lifted out of the pelvis by making an arc.

To compare maternal and fetal morbidity between Patwardhan method of second stage LSCS and conventional "push and pull" method.

\section{METHODS}

This is a retrospective study of all LSCS performed in second stage of labour during 3 years from January 2016 to December 2018 in Smt. Kashibai Navale Medical College Pune.

Women with single fetus at term in cephalic position with second stage needing caesarean section were included in the study.

The decision for performing Patwardhan method or to go with push approach was taken in the operation theatre by the operating surgeon

\section{Patients were divided into 2 groups}

Group A - consisted of all cases delivered by Patwardhan method.

Group B - consisted of all cases delivered by Push method.
All the included patients were studied for immediate intraoperative complications like extension of incision, injury to surrounding structures, excessive bleeding, need for blood transfusion and post-operative complications fever, wound dehiscence, puerperal sepsis up to 6 weeks postpartum. Neonatal complications like birth injuries and NICU admissions were compared in both groups. Intraoperative, postoperative and neonatal complications between two study groups were compared with paired ' $t$ ' test to find out $\mathrm{p}$ value, before coming to a conclusion.

\section{Inclusion criteria}

- All the patients who underwent second stage LSCS with single fetus at term in cephalic position for various indications during study period

- Patients with proper records about method of baby delivery

- $\quad$ Patients with who completed follow up visits upto 6 weeks.

\section{Exclusion criteria}

- Patients who underwent second stage LSCS after failed forceps or ventouse

- Patients who underwent second stage LSCS with multiple foetuses and non-vertex presentation

- Patients who had elective LSCS in LSCS in first stage of labour

- Patients with incomplete records

- Patients who are lost to follow up.

\section{RESULTS}

A total of 89 patients underwent second stage LSCS from January 2016 to December 2018.

A total of 37 patients were delivered by Patwardhan's method and 52 patients were delivered by Push method

Student $\mathrm{t}$ test was used appropriately for calculation of value and a p $<0.05$ was considered statistically significant.

Both the groups were comparable in terms of age and parity of patients. Second stage sections are seen more commonly in primigravida than in multigravida.

Table 1: Age wise distribution.

\begin{tabular}{|llll|}
\hline Age group & Group A (Patwardhan, $n=37)$ & Group B (Push, $\mathbf{n = 5 2})$ & P value \\
\hline$<24$ years & 17 & 24 & $>0.05$ \\
\hline $25-30$ years & 14 & 19 & \\
\hline$>30$ years & 6 & 9 & \\
\hline
\end{tabular}


Table 2: Distribution of cases according to gravid status.

\begin{tabular}{|llll|}
\hline Gravida & Group A (Patwardhan, $\mathbf{n = 3 7})$ & Group B (Push, n=52) & p value \\
\hline Primigravida & 26 & 37 & $>0.05$ \\
\hline Gravida 2 & 9 & 11 & \\
\hline Gravida 3 or more & 2 & 4 & \\
\hline
\end{tabular}

Table 3: Distribution according to gestational age and fetal weight.

\begin{tabular}{|lll|l|}
\hline Gestational age & Group A (Patwardhan) & Group B (Push) & p value \\
\hline Mean gestational age & $38.26 \pm 1.0$ & $39.85 \pm 0.72$ & $>0.05$ \\
\hline Mean fetal weight at birth & 3100 & 3060 & $>0.05$ \\
\hline
\end{tabular}

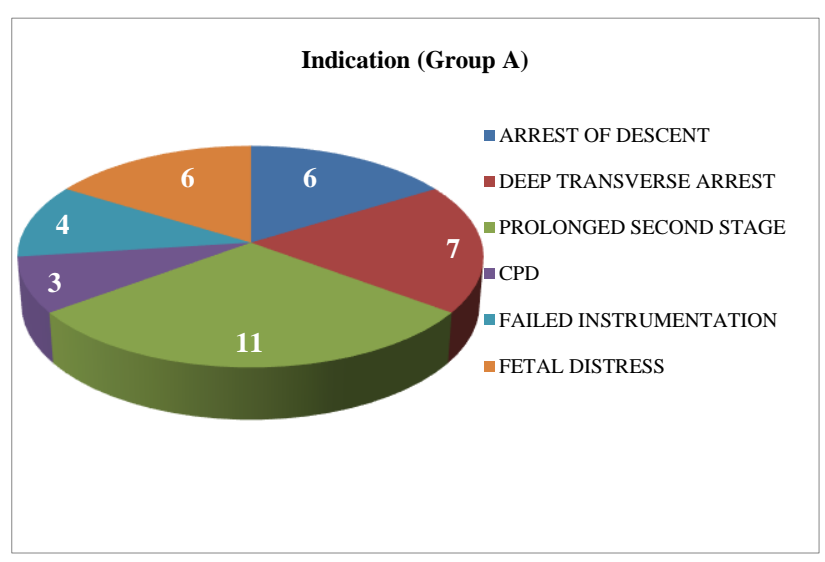

Figure 1: Indications of caesarean in Patwardhan group.

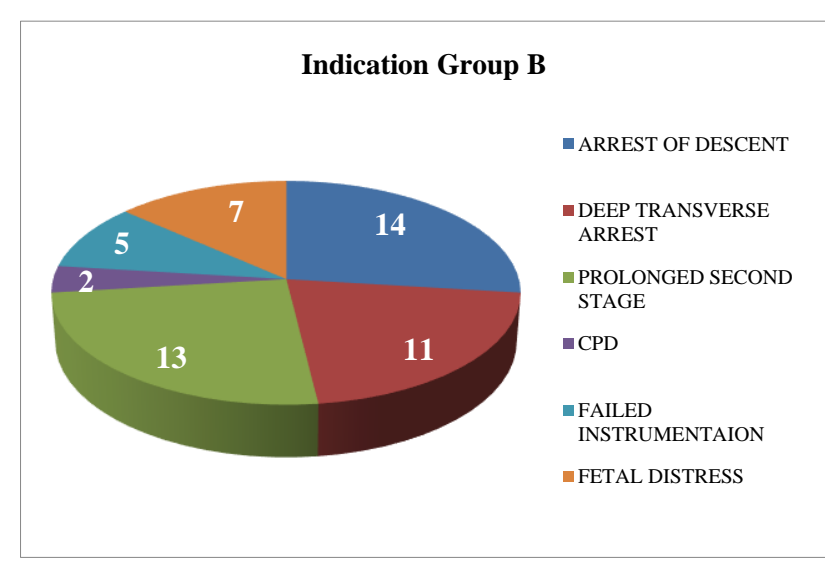

Figure 2: Indications of cesarean in Push and Pull group.

Table 4: Maternal morbidities.

\begin{tabular}{|llll|}
\hline Maternal morbidities & Group A (Patwardhan) $(\mathbf{n = 3 7})$ & Group B (Push) $(\mathbf{n = 5 2})$ & p value \\
\hline Extension of uterine incision & 3 & 19 & $<0.05^{*}$ \\
\hline Bladder injury & 0 & 1 & $>0.05$ \\
\hline Blood transfusion needed & 3 & 11 & $<0.05^{*}$ \\
\hline Traumatic PPH & 2 & 7 & $<0.05^{*}$ \\
\hline Need for hysterectomy & 0 & 1 & $>0.05$ \\
\hline Post-operative fever & 7 & 19 & $<0.05^{*}$ \\
\hline Wound gape & 2 & 5 & $>0.05$ \\
\hline
\end{tabular}

Table 5: Fetal morbidity.

\begin{tabular}{|llll|}
\hline Fetal morbidities & Group A (Patwardhan) $(\mathbf{n = 3 7})$ & Group B (Push) & $(\mathbf{n = 5 2})$ \\
\hline APGAR at 1 min & & & p value \\
\hline$\leq 7$ & 7 & 15 & $>0.05$ \\
\hline$>7$ & 30 & 37 & $>0.05$ \\
\hline APGAR at 5 mins & & & $<0.05^{*}$ \\
\hline$\leq 7$ & 3 & 11 & $>0.05$ \\
\hline$>7$ & 34 & 41 & $<0.05^{*}$ \\
\hline Need for NICU care & 6 & 17 & $<0.05^{*}$ \\
\hline Ventilator care & 1 & 5 & $>0.05$ \\
\hline Still births & 0 & 1 & $<0.05^{*}$ \\
\hline Neonatal deaths & 2 & 6 & $<0.05$ \\
\hline Fetal injuries & 1 & 3 & \\
\hline
\end{tabular}


Most common indication- prolonged second stage of labour followed by deep transverse arrest.

Uterine incision extension was more in the push and pull method when compared to Patwardhan technique (3 in Patwardhan 19 in push and pull method, $\mathrm{p}<0.05$ ).

Same was true for the traumatic PPH (2 in Patwardhan 7 in push and pull method, $\mathrm{p}<0.05$ ) and blood transfusion which was significantly high in push and pull method as compared. (3 in Patwardhan 11 in push and pull method, $\mathrm{p}<0.05)$ (Table 4).

Post-operative fever ( 7 in Patwardhan, 19 in push and pull method, $\mathrm{p}<0.05$ ) wound gape ( 2 in Patwardhan, 5 in push and pull method, $\mathrm{p}<0.05)$. Although it is significantly high in push and pull method but we cannot deny other causes of fever and wound gape which can be reason for that.

Neonatal morbidity was significantly less in Patwardhan's method as compared to Push method.

\section{DISCUSSION}

Obstructed labor accounts for $9.5 \%$ of total maternal deaths in India. ${ }^{3}$ This high incidence is mainly due to traditional beliefs and practices, neglected obstetric care, poor utilization of available health services, and poor transport facilities. Caesarean sections done in second stage of labour with impacted fetal heads are associated with increased trauma to lower uterine segment and associated structures, as well as, increased haemorrhage and infections.

Caesarean sections done at full cervical dilatation with impacted fetal heads are technically difficult and they are associated with an increased incidence of maternal and fetal morbidities. ${ }^{4}$

A prolonged second stage of labour increases the attenuation of lower uterine segment and impaction of fetal head, which gives rise to a thin, easily lacerated lower uterine segment and cervix, which is predisposed to more extensions while delivering fetal head. Extensions may also occur in cervix and broad ligament, thus increasing incidence of haemorrhage and need for blood transfusions and contributing to maternal morbidity. Chances of fetal injuries in the form of skull fracture and intra ventricular hemorrhage are higher in second stage cesarean section. ${ }^{5}$

Obstetric confounding factors like parity, maternal age and fetal factors like gestational age, mean birth weight were comparable in both the groups.

Results of uterine incision extension are very similar to studies done by Beeresh CS et al (8.69\% versus $34.61 \%)$, Mukhopadhyay $\mathrm{P}$ et al (6\% versus $64 \%)$, Khosla et al
${ }_{8}^{(0 \% \text { versus } 24 \%)} 8$ and Saha PK et al (0\% versus $\left.22 \%\right) .^{6-}$

Table 6: Extension of uterine incision comparison with other authors.

\begin{tabular}{|lll|}
\hline $\begin{array}{l}\text { Extension of uterine } \\
\text { incision }\end{array}$ & $\begin{array}{l}\text { Patwardhan } \\
\text { method }\end{array}$ & $\begin{array}{l}\text { Push } \\
\text { method }\end{array}$ \\
\hline Our study & $8.10 \%$ & $37 \%$ \\
\hline Beeresh CS et al & $8.69 \%$ & $4.61 \%$ \\
\hline Mukhopadhyay P et al & $6 \%$ & $64 \%$ \\
\hline Saha PK et al & $0 \%$ & $22 \%$ \\
\hline Khosla et al $^{3}$ & $0 \%$ & $24 \%$ \\
\hline
\end{tabular}

Need for post-operative blood transfusion in our study was $8.10 \%$ in Patwardhan's method and $21.15 \%$ in Push method which is similar to studies of Saha PK et al, $(8.6 \% \text { versus } 27.3 \%)^{8}$

Prolonged second stage of labor was associated with unintentional hysterotomy extensions (40\% versus $26 \%$; $\mathrm{P}=.03){ }^{9}$

Need for post-operative blood transfusion is an indirect consequence of extension of uterine incision and the resultant blood loss.

Incision extension related complications like bladder injury, need for hysterectomy, need for post-operative blood transfusion were all more in Push group.

Limitations of this study were presence of senior obstetricians or obstetrician trained in doing Patwardhan's method is needed during all second stage caesarean section.

\section{CONCLUSION}

As the maternal and fetal complications are seen to be considerably less in Patwardhan's method than the conventional Push method

Our study concludes that Patwardhan's method for delivering baby in second stage LSCS confers greater advantage.

Patwardhan's method can be used primarily in cases of second stage sections to significantly reduce the maternal and fetal morbidity.

\section{ACKNOWLEDGMENTS}

Authors would like to thank to institutional head, Head of Department of Obstetrics and Gynecology and all our colleagues from Department of Obstetrics and Gynecology Smt. Kashibai Navale Medical College and General Hospital for providing necessary help in this project. 
Funding: No funding sources

Conflict of interest: None declared

Ethical approval: Not required

\section{REFERENCES}

1. Freeman RK. Evaluation of cesarean delivery. American College of Obstetricians and Gynecologists Women's Health Care Physicians; 2000.

2. Mukhopadhyay P, Naskar T, Dalui R, Hazra S, Bhattacharya D. Evaluation of Patwardhan's technica four-year study in a rural teaching hospital. J Obstet Gynecol India. 2005;55:244-6.

3. Khosia AH, Dahiya K, Sangwan K. Cesarean section in a wedged head. Ind J Med Sci. 2003;57:187-91.

4. Fasubaa OB, Ezechi OC, Orji EO, Ogunniyi SO, Akindele ST, Loto OM, et al. Delivery of the impacted head of the fetus at caesarean section after prolonged obstructed labor, a randomized comparative study of two methods. J Obstet Gynecol. 2002;22:375-8.

5. Hager RM, Daltviet AK, Hofoss D, Nilson ST, Oian $\mathrm{P}$, Henriksen T. Complications of cesarean deliveries: rates and risk factors. Am $\mathrm{J}$ Obstet Gynecol. 2004;190:428-34.
6. Murphy DJ, Liebling RE, Verity L, Swingler R, Patel R. Early maternal and neonatal morbidity associated with operative delivery in second stage of labour: a cohort study. Lancet. 2001;358:1203-7.

7. Beeresh CS, Doopadapalli D, Shivaraju P, Lingegowda K. Disengagement of the deeply engaged fetal head during caesarean section in advanced labor: patwardhan versus push extraction. Int J Reprod Contracept Obstet Gynecol. 2016;5:6873.

8. Saha PK, Gulati R, Goel P, Tandon R, Huria A. Second stage caesarean section: evaluation of patwardhan technique. J Clin Diagnos Rese. 2014;8(1):93.

9. Sung JF, Daniels KI, Brodzinsky L, El-Sayed YY, Caughey AB, Lyell DJ. Caesarean delivery outcome after a prolonged second stage of labor. Am J Obstet Gynecol. 2007;197:306:e1-5.

Cite this article as: Hol K, Trivedi S, Jaiswal S, Darawade S. Comparison of maternal and fetal morbidity between Patwardhan method of second stage lower segment caesarean section and conventional "push and pull" method. Int J Reprod Contracept Obstet Gynecol 2019;8:4538-42. 